\title{
Editor's Golumn
}

ONE CAN NEVER be certain of these things, but it is my impression that this issue of PMLA is an unusually interesting one. An editor's views are naturally suspect, so let me share with you some of the reactions to the articles expressed by consultant readers and by members of our Advisory Committee and Editorial Board.

It has been a number of years since $P M L A$ has published an article on teeth, and when Theodore Ziolkowski's essay on psychodontia and sociodontia reached the Editorial Board, I think we all approached it with some apprehension. Our fears were, to say the least, unwarranted, and the Board's reaction can be summed up by the comment of the member who, dazzled by the essay's range of reference and the author's knowledge and wit, said, "wow." Members of the Board, I hasten to add, are considerably more articulate than this remark might indicate, but then we don't receive many articles that take us from Egyptian iconography and the Old Testament to Koestler, Graham Greene, and Günter Grass-all in connection with dentists and teeth. That any single article can be truly of interest to every one of $P M L A$ 's 30,000 readers is an idea that has been ridiculed on more than one occasion this past year, but $I$ suspect that anyone with a good set of uppers and lowers will find Ziolkowski's story to be a fascinating one.

The Editorial Board was equally enthusiastic about the second article in this issue, Howell Chickering's study of Bede's Death-Song. That five-line "durable little poem," as Chickering calls it, is surely not one of the classics of English literature. But I think all of us on the Board were enthralled by this essay and thus sympathized with the consultant reader-a hard-nosed critic of considerable reputewho was forced to admit that "for the first time in my life, I find myself unreservedly enthusiastic about an article. Working on a poem previously ignored by critics (including myself), Chickering manages to place it in a psychological and literary context that converts it into a piece of genuine interest and value." I think anyone interested in literature (and life and death) will find reading this essay to be a rewarding experience.

Articles on Surrey and Swift might not appear to have much in common with one on Bede, but C. W. Jentoft's analysis of five of Surrey's elegies and Thomas Gilmore's of five of Swift's scatological poems also force us to take a fresh look at minor works that are perhaps of greater interest than we have thought. Whether or not readers conclude that Jentoft has, as one specialist consultant suggested, "rehabilitated Surrey," I think we would all agree that his is a cogent and spirited defense which skillfully shows how manipulation of convention can in itself be a form of originality. It is an invaluable study for anyone who teaches Surrey, and should also be of special interest to anyone concerned with things elegiac. Those concerned with things scatological will not, of course, find much of interest in Surrey's elegies; poems like Swift's Strephon and Chloe and The Lady's Dressing Room are more promising. As one who even on a first reading knew full well what Celia was up to. I had never considered such poems to be thigh-slappers and would not have been inclined to argue that they were "comic masterpieces." But Gilmore's stress on the comic elements is long overdue, and one need not be a Swift scholar to follow, and enjoy, the argument.

Heroes and heroism are integral to the next two articles in this issue, although William Goode's concern with the heroic quest in $L e$ Cid takes him on a far different journey from Gustaaf van Cromphout's exploration of Emerson and the dialectics of history. Noting that Goode's study of hand, heart, and mind goes beyond the play itself, even beyond Corneille, in analyzing complexities in the very idea of heroism, all readers agreed that Goode's article is, well, just that-and "rich," "informed," "stimulating," "provocative," and "refreshingly original." So too van Cromphout's study. As one reader put it, "although not especially interesting because of its methodology, the article is valuable for its learning, its synthesis of scholarship, and fresh insight-old virtues still useful, and to be reminded of."

The 1973 volume of the MLA International Bibliography lists 164 items on James and Conrad, all published in a single year. I do not know how many articles on these two authors are submitted to $P M L A$ each year - considerably more than on Bede and Surrey - and I admit to some astonishment when an article on James or Conrad is recommended to the Editorial Board as having something to say that is both fresh and important. Ruth Yeazell's anatomy of the "awfully unutterable" in James's 
late novels is one such case, for it throws new light not only on James's development as a writer, but on the larger problem of the use of dialogue in fiction, employing a methodology that could well be extended beyond James. One reader simply termed it "illuminating - and luminous." Lloyd Fernando's article on Conrad is, I believe, equally so. Noting in his opening paragraphs that there would seem to be little more to be said or done in regard to Conrad's knowledge of the Malaysian Archipelago, Fernando, writing from the University of Malaya, proceeds to unfold an entirely new version of Conrad's "outcasts." Although concentrating on a relatively minor novel, this article is also one that transcends the particular and enables us to see Conrad's total significance more clearly than before. I quote once more from one of our consultant readers: "From now on I personally will read Conrad with new interest and I expect new pleasure. This article is the product of an exceptionally fine literary mind."

The issue concludes with Charles Altieri's explanation of how objective image and act of mind combine in modern poetry. It is one of those essays, of which PMLA has published a number in the past year, that Board members suspect will arouse a certain amount of reader antagonism, for, as one member put it, this is "one man's modernism." The article's chief value, however (in addition to original commentaries on individual works such as Arnold's "Empedocles" and Williams" "Red Wheelbarrow"), is in its synthesis of modernist literature, a "brilliant synthesis," as our specialist consultant has put it. Whether they agree or not, I trust readers will find this essay to be provocative, and perhaps that is what a scholarly journal is ultimately all about.

In a field that has not suffered for want of specialized scholarly journals, $P M L A$ remains one of the relatively few that attempt to run the gamut from $\mathrm{A}$ to $\mathrm{Z}$. I don't know how far up or down the alphabet this particular issue goes, but a staff colleague has pointed out that I have (quite accidentally, I assure you) arranged the articles from Ziolkowski to Altieri. These things happen.

William D. SChaefer

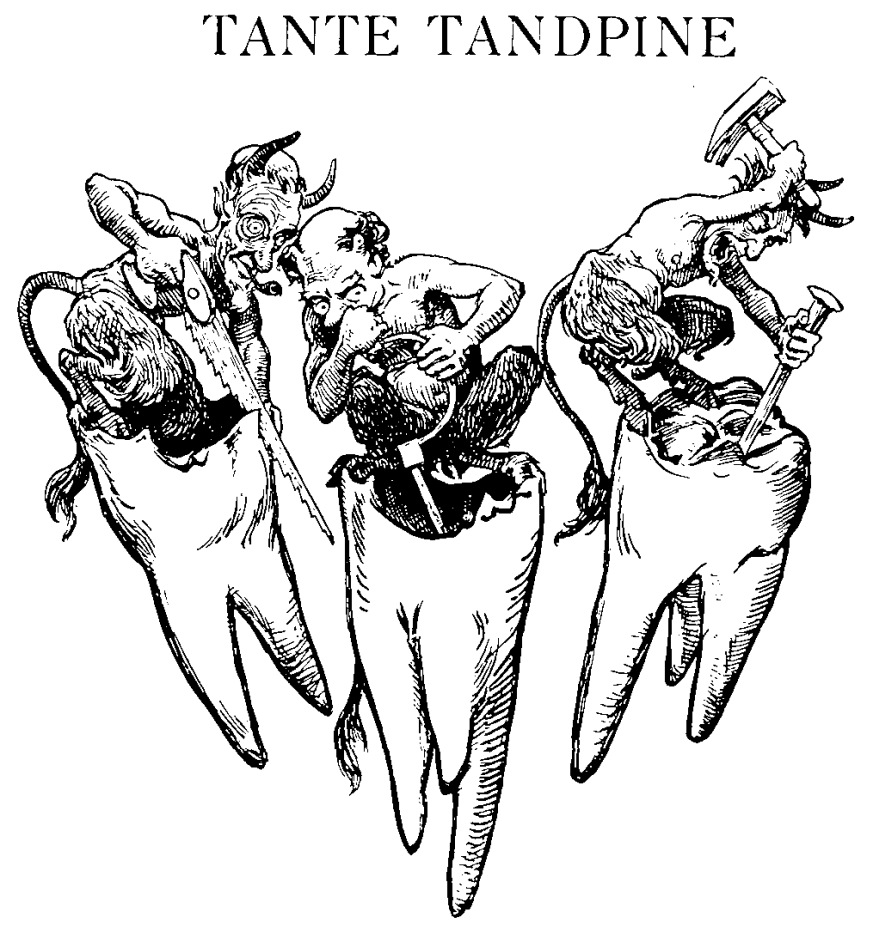

